\title{
Copper Reduces A $\beta$ Oligomeric Species and Ameliorates Neuromuscular Synaptic Defects in a C. elegans Model of Inclusion Body Myositis
}

\author{
Daniela L. Rebolledo, ${ }^{1 \star}$ Rebeca Aldunate, ${ }^{1,2 *}$ Rebecca Kohn, ${ }^{3}$ Iván Neira, ${ }^{1,4}$ Alicia N. Minniti, ${ }^{1}$ and Nibaldo C. Inestrosa ${ }^{1}$ \\ ${ }^{1}$ Centro de Regulación Celular y Patología "Joaquín V. Luco", Millennium Institute of Fundamental and Applied Biology, Centro de Envejecimiento y \\ Regeneración, Facultad de Ciencias Biológicas, Pontificia Universidad Católica de Chile, 8331010 Santiago, Chile, ${ }^{2}$ Escuela de Biotecnología, Universidad \\ Santo Tomás, 8370003 Santiago, Chile, ${ }^{3}$ Department of Biology, Ursinus College, Collegeville, Pennsylvania 19426-1000, and ${ }^{4}$ Departamento de Tecnología \\ Médica, Facultad Ciencias de la Salud, Universidad de Antofagasta, Antofagasta 1240000, Chile
}

Alzheimer's disease and inclusion body myositis (IBM) are disorders frequently found in the elderly and characterized by the presence of amyloid- $\beta$ peptide $(\mathrm{A} \beta$ ) aggregates. We used Caenorhabditis elegans that express $\mathrm{A} \beta$ in muscle cells as a model of IBM, with the aim of analyzing $\mathrm{A} \beta$-induced muscle pathology and evaluating the consequences of modulating $\mathrm{A} \beta$ aggregation.

First, we tested whether the altered motility we observed in the $\mathrm{A} \beta$ transgenic strain could be the result of a compromised neuromuscular synapse. Our pharmacological analyses show that synaptic transmission is defective in our model and suggest a specific defect on nicotine-sensitive acetylcholine receptors (AChRs). Through GFP-coupled protein visualization, we found that synaptic dysfunction correlates with mislocalization of ACR-16, the AChR subunit essential for nicotine-triggered currents.

Histological and biochemical analysis allowed us to determine that copper treatment increases the amyloid deposits and decreases $\mathrm{A} \beta$ oligomers in this model. Furthermore, copper treatment improves motility, ACR-16 localization, and synaptic function and delays $\mathrm{A} \beta$-induced paralysis. Our results indicate that copper modulates $\mathrm{A} \beta$-induced pathology and suggest that $\mathrm{A} \beta$ oligomers are triggering neuromuscular dysfunction. Our findings emphasize the importance of neuromuscular synaptic dysfunction and the relevance of modulating the amyloidogenic component as an alternative therapeutic approach for this debilitating disease.

\section{Introduction}

Alzheimer's disease (AD) and inclusion body myositis (IBM) are disorders frequently found in the older population (Askanas and Engel, 2007; Selkoe, 2007). Whereas both diseases affect different tissues, nervous system and muscle, respectively, they have similar features, and most molecules known to be involved in IBM are also present in $\mathrm{AD}$ (Rebolledo et al., 2008). The amyloid- $\beta$ (A $\beta$ ) peptide is the main constituent of both senile plaques (SPs) in $\mathrm{AD}$ (Masters et al., 1985) and intracellular amyloid aggregates in skeletal muscle cells

Received Jan. 20, 2011; revised April 28, 2011; accepted May 16, 2011.

Author contributions: D.L.R., R.A., A.N.M., and N.C.I. designed research;D.L.R., R.A., I.N., and A.N.M. performed research; R.K. contributed unpublished reagents/analytic tools; D.L.R., R.A., I.N., and A.N.M. analyzed data; D.L.R., A.N.M., and N.C.I. wrote the paper.

${ }^{*}$ D.L.R. and R.A. contributed equally to this work.

This work was supported by Fondo de Financiamiento de Centros de Excelencia en Investigación Biomedicine Grant 13980001, the Millennium Institute of Fundamental and Applied Biology, the Center for Aging and Regeneration, Programa de Financiamiento Basal 12/2007, the Base Financing Program for Scientific and Technological Centers of Excellence, and Comisión Nacional de Investigación Cientifica y Tecnológica. D.L.R. has a predoctoral fellowship from CONICYT. We thank Dr. Michael M. Francis (University of Massachusetts, Worcester, MA) for his kind gift of the ACR-16::GFP and UNC-29::GFP strains, Dr. Enrique Toledo (Pontificia Universidad Católica de Chile) for help with BSB staining and A11 dot-blot assay, Dr. Christopher Link (University of Colorado, Boulder, $\mathrm{C} 0$ ) for his generous gift of $C$. elegans strains that express $A \beta$ proteins in body wall muscle cells, and Dr. Olivia Casanueva for the $s k n-1$ RNAi clone.

Correspondence should be addressed to Nibaldo C. Inestrosa and Alicia N. Minniti, Center for Aging and Regeneration, Facultad de Ciencias Biológicas, P. Universidad Católica de Chile, Alameda \#340, P.O. Box 114-D, 8331010 Santiago, Chile. E-mail: ninestrosa@bio.puc.cl or aminniti@bio.puc.cl.

DOI:10.1523/JNEUROSCI.0336-11.2011

Copyright $\odot 2011$ the authors $\quad 0270-6474 / 11 / 3110149-10 \$ 15.00 / 0$ in IBM (Askanas and Engel, 2006). Because of the inflammatory component of IBM, immunosupressor therapies have been tried in patients without satisfactory results (Dalakas et al., 2001; Barohn et al., 2006). Therefore, the amyloidogenic component acquires greater relevance, and $\mathrm{A} \beta$ modulation may provide an alternative therapeutic approach.

It is not yet clear whether the amyloid aggregates trigger the onset of amyloidogenic diseases or whether they are the end product of the cell protective machinery. Current evidence shows that $\mathrm{A} \beta$ oligomers, rather than SPs or $\mathrm{A} \beta$ fibrils, are the toxic species (Lesne et al., 2006; Lacor et al., 2007). On the other hand, although it is clear that SPs are structured as metal-enriched aggregates that accumulate $\mathrm{Cu}^{2+}, \mathrm{Fe}^{3+}$, and $\mathrm{Zn}^{2+}$ (Lovell et al., 1998 ) and that the aggregation state of $\mathrm{A} \beta$ peptide is modulated by metals and metal chelators (Bush et al., 1994b; Cherny et al., 2001), the role of copper as deleterious or beneficial in the context of amyloidogenic and neurodegenerative diseases is controversial (Strausak et al., 2001; Cerpa et al., 2005; Kessler et al., 2005).

Caenorhabditis elegans experimental models for AD and IBM are strains that overexpress the human $\mathrm{A} \beta_{3-42}$ peptide (McColl et al., 2009). When $A \beta$ is expressed in muscle cells, pathological behaviors include paralysis in $\mathrm{A} \beta$ thermo-inducible strains (Link et al., 2003) and slow movement in liquid medium in constitutive A $\beta$ strains (Minniti et al., 2009). Serotonin hypersensitivity, altered chemotaxis, and learning deficits have been reported when $\mathrm{A} \beta$ is expressed in neurons (Wu et al., 2006; Dosanjh et al., 2010). 
The toxic $A \beta$ species responsible for these effects have not been thoroughly identified, but they are likely to be $\mathrm{A} \beta$ oligomers $(\mathrm{Wu}$ et al., 2006) rather than mature $\mathrm{A} \beta$ amyloid aggregates.

It is currently known that the neurotoxic effects of $A \beta$ peptide in $\mathrm{AD}$ compromise synaptic function before the onset of cell death (Selkoe, 2002). For instance, there is a decrease of synaptic proteins before the onset of plaque formation in murine models of $\mathrm{AD}$ (Mucke et al., 2000) and AD patients (Masliah et al., 2001a,b). Given the similarities between AD and IBM, we hypothesize that in IBM the early pathological events might be associated with the neuromuscular synapse.

We found that a C. elegans model of IBM develops functional and structural defects at the neuromuscular level. We also show that copper can improve the $\mathrm{A} \beta$-induced dysfunction and decrease soluble oligomeric $\mathrm{A} \beta$ species. Our findings emphasize the importance of neuromuscular synaptic dysfunction in IBM and the relevance of modulating the amyloidogenic component as an alternative therapeutic approach.

\section{Materials and Methods}

Strains. Transgenic strains CL2120 (dvIs14[unc-54/hA $\beta 1-42(\mathrm{pCL} 12)+$ mtl-2::GFP (pCL26)]), CL2122 (dvIs15[pPD30.38(unc-54 vector)+ $m t l-2:: G F P($ pCL26)]) (Fay et al., 1998), CL2006 (dvIs2[pCL12(unc-54/hA $\beta 1-$ 42) + pRF4(rol-6(su1006)]) (Link, 1995), CL6176 (smg-1 (cc546)I; dvIs19(Pgst4::GFP)III;+/nT1(unc d;let-?IV;V);dvIs27 [pAF29(Pmyo-3::A 342$)+$ pRF4]X), and CL6180 (smg-1(cc546)I; dvIs19(Pgst-4::GFP)III; skn-1(zu67) IV/nT1(unc d;let-?IV;V); dvIs27[pAF29 (Pmyo-3::A $\beta 42)+$ pRF4]) (Dostal et al., 2010) were a gift from Dr. C. Link, University of Colorado, Boulder, CO.

Strains carrying GFP fusion protein Pmyo3::ACR-16::GFP or Punc-29::UNC-29::GFP (Francis et al., 2005) were a gift from Dr. M. Francis, University of Massachusetts, Worcester, MA.

RB918 (acr-16(ok789)V), CB193 (unc-29(e193)I), CL4176 (smg-1(cc546ts)I; $d v I s 27[\mathrm{pAF} 29$ (myo-3/A $\beta 1-42 /$ let UTR) + pRF4(rol-6(su1006)]X), and its standard control CL802 (smg-1(cc546ts)I; rol-6(su1006)II) (Link et al., 2003) were obtained from the Caenorhabditis Genetics Center. We constructed the following strains by standard genetic crosses: ANM30 (dvIs2[pCL12(unc-54/hA $\beta 1-$ 42) + pRF4(rol-6(su1006)]; Pmyo3::ACR-16::GFP); ANM31 (rol-6(su1006)II; Pmyo3::ACR-16::GFP); ANM40 (dvIs14[unc-54/A $\beta 1-42($ pCL12) + mtl-2:: GFP(pCL26)]; acr-16(ok789)V); and ANM43 (dvIs2[pCL12(unc-54/hA $\beta 1-$ 42) + pRF4 (rol-6(su1006); Punc-29::UNC-29::GFP).

Nematode propagation and treatments. The worms were cultured on regular nematode growth medium (NGM) culture plates seeded with the bacterial strain OP50 (Brenner, 1974). Worm strains were maintained at $20^{\circ} \mathrm{C}$, except for CL4176, CL802, CL6176, and CL6180, which were maintained at $16^{\circ} \mathrm{C}$, and shifted to $23-25^{\circ} \mathrm{C}$ to induce $\mathrm{A} \beta$ expression. For copper treatment, $\mathrm{NGM}$ was supplemented with $\mathrm{CuCl}_{2}$ (Sigma) at the indicated concentrations, and the worms were treated from the embryo stage (CL2120, Cl2122, and CL2006 strains) or from the time of temperature upshift (CL4176, CL802, CL6176, and CL6180 strains) until the experiments were performed.

To obtain developmentally synchronized populations, gravid hermaphrodites were subjected to the hypochlorite method (Lewis and Fleming, 1995), and the resulting eggs were seeded onto the previously described agar plates. The animals were collected at indicated times by washing the plates with M9 buffer (Lewis and Fleming, 1995), precipitated by gentle centrifugation and removal of M9. The nematodes were then processed as described below. Hermaphrodite worms were used for all the experiments.

Thioflavine-S staining. Thioflavine-S (Th-S) staining was performed as described previously (Fay et al., 1998). Briefly, the worms washed from the plates were fixed with $4 \%$ paraformaldehyde in PBS, $\mathrm{pH} 7.4$, for $24 \mathrm{~h}$ at $4^{\circ} \mathrm{C}$. The fixative solution was removed, replaced by permeabilization solution (125 mm Tris, pH 7.4, 1\% Triton X-100, 5\% $\beta$-mercaptoethanol), and incubated at $37^{\circ} \mathrm{C}$ for $24 \mathrm{~h}$. The animals were washed three times in PBS-T (PBS plus $0.1 \%$ Triton X-100), stained in $0.125 \%$ Th-S (Sigma) in $50 \%$ ethanol for $2 \mathrm{~min}$, and destained for another $2 \mathrm{~min}$ in $50 \%$ ethanol. The stained samples were resuspended in PBS and mounted in fluorescence mounting medium (Dako).
BSB staining. (Trans, trans)-1-bromo-2,5-bis-(3-hydroxycarbonyl-4hydroxy) styrylbenzene (BSB) was purchased from AnaSpec and prepared according to the manufacturer's instructions. The assay was performed according to the protocol established by Toledo and Inestrosa (2009) with the following modifications. Briefly, synchronized worms were cultured and collected at different stages, fixed with $4 \%$ paraformaldehyde, and permeabilized as indicated above. Then, the worms were incubated with BSB $\left(0.02 \%\right.$ resuspended in $50 \%$ ethanol) for $4 \mathrm{~h}$ at $37^{\circ} \mathrm{C}$. The worms were then washed with lithium carbonate $(1 \mathrm{M})$, washed with water, and finally mounted for microscopy observation. BSB staining intensity was estimated using the WCIF ImageJ software.

Microscopy. Fluorescence images were acquired using the same exposure parameters with a $40 \times$ or $100 \times$ objective in a BX51 microscope (Olympus). The microscope was equipped with a digital camera, Micropublisher 3.3 RTV (JH Technologies). For ACR-16::GFP and UNC-29::GFP distribution analysis, 1- to 2-d-old worms were anesthetized with $20 \mathrm{~mm} \mathrm{NaN}_{3}$ and photographed.

Thrashing assays. Individual animals of the same age were placed on an $80 \mu \mathrm{l}$ drop of M9 buffer. After a 2 min recovery period, the worms were recorded for 1.5 min with a digital camera (Nikon Coolpix-4500), and the thrashes were counted while replaying the video in slow motion. A thrash is defined as a change in the direction of bending at the midbody (Miller et al., 1996).

Neuromuscular synaptic transmission assay. Worms (25-30) of the same age were place on assay plates (NGM supplemented with $0.25 \mathrm{~mm}$ levamisole, $31 \mathrm{~mm}$ nicotine, or $20 \mathrm{~mm}$ nicotine). We then analyzed the drug-induced paralysis over time (Mahoney et al., 2006). As an internal control, we use the RB1131 [lev-10(ok1154)I] strain that is nicotine and levamisole resistant, because lev-10 is required for clustering of postsynaptic proteins (Gally et al., 2004).

Temperature-induced paralysis assay. The assays were performed as described by Wu et al. (2006), with the following modification. At the L3 stage, worms were moved to newly seeded NGM plates with or without copper supplementation, and the temperature was upshifted to $23-25^{\circ} \mathrm{C}$. The ratio of paralyzed to nonparalyzed individuals (90-120 worms per plate) over time was plotted.

RNAi knockdown. These experiments were performed as described by Dostal et al. (2010) using the corresponding Escherichia coli from the Ahringer RNAi feeding library. Exposure to the $s k n-1$ RNAi clone caused the treated animals to lay over $99 \%$ dead eggs, the expected $s k n-1$ phenotype.

Protein extraction. Worms were collected from the plates with M9 buffer, transferred to tubes, centrifuged, and washed two times to eliminate bacteria. The final worm pellet was resuspended in $100 \mu \mathrm{l}$ of lysis buffer in the presence of protease inhibitors (50 mM HEPES, pH 7.5, 6 mM $\mathrm{MgCl}_{2}, 1$ mM EDTA, 75 mm sucrose, 25 mm benzamidine, 1 mm DTT, $1 \%$ Triton $\mathrm{X}-100)$ and frozen at $80^{\circ} \mathrm{C}$. Samples were sonicated three times on ice for $15 \mathrm{~s}$.

Western blot analyses. For $\mathrm{A} \beta$ analysis, the crude protein extracts were centrifuged $5 \mathrm{~min}$ at 10,000 rpm to eliminate cuticles. The supernatant was transferred to a new tube, and total protein content was quantified using the BCA kit (Pierce). Equal protein quantities were suspended in loading buffer (50 mm Tris- $\mathrm{HCl}, \mathrm{pH} 6.8,100 \mathrm{~mm}$ DTT, 5\% SDS, $10 \%$ glycerol, $0.02 \%$ bromophenol blue, $5 \% \beta$-mercaptoethanol) and boiled for $3 \mathrm{~min}$ (adapted from Wu et al., 2006). The samples were subjected to electrophoresis on Tris-Tricine polyacrylamide gels at a constant voltage $(100 \mathrm{~V})$ at $4^{\circ} \mathrm{C}$. The proteins were then transferred to PVDF membranes for $2 \mathrm{~h}$ at $4^{\circ} \mathrm{C}(300 \mathrm{~mA})$. The membranes were boiled in PBS for 3 min before blocking with a solution of PBT (PBS and $0.1 \%$ Tween 20) plus $5 \%$ milk for $1 \mathrm{~h}$ at room temperature. We used the mouse anti-A $\beta$ monoclonal antibody $6 \mathrm{E} 10$ (Millipore) at 1:1000 dilution or mouse anti- $\alpha$-tubulin monoclonal antibody (Sigma) at 1:5000 dilution overnight at $4^{\circ} \mathrm{C}$. We used goat anti-mouse HRP as a secondary antibody.

Dot-blot analyses. Equal protein quantity was spotted on $0.45 \mathrm{~mm}^{2}$ nitrocellulose (Millipore), blocked with PBS-T gelatin (PBS, 0.05\% Tween $20,0.3 \%$ gelatin), and incubated using the anti-oligomeric antibody A11 (Millipore) at 1:5000 dilution for $2 \mathrm{~h}$ at room temperature or overnight at $4^{\circ} \mathrm{C}$. We used goat anti-rabbit HRP as a secondary antibody. 
Statistical analyses. The data were analyzed using GraphPad Prism 5 software. Values are presented as mean $\pm \mathrm{SE}$, and $t$ test analysis was used to compare treatments, except for mislocalization of GFP fusion proteins where a $Z$ test was used to compare proportions $\left({ }^{\star} p \leq 0.05 ;{ }^{* *} p \leq 0.01\right.$; $\left.{ }^{* * *} p \leq 0.001\right)$.

\section{Results}

Transgenic C. elegans expressing A $\beta$ show synaptic defects Under normal culture conditions, we previously observed that adult worms expressing $\mathrm{A} \beta$ constitutively move significantly slower than the controls that do not express $A \beta$ (Minniti et al., 2009). We hypothesized that the compromised motility of $A \beta$ transgenic worms in liquid medium could be, at least in part, the result of $\mathrm{A} \beta$-induced defects at the neuromuscular junction $(\mathrm{NMJ})$, leading to synaptic transmission failure and decreased motor capacity. To test this hypothesis, we performed pharmacological assays with drugs known to affect NMJ function. Because $A \beta$ is expressed in muscle cells, we evaluated postsynaptic NMJ function using levamisole and nicotine, agonists of the acetylcholine receptors (AChRs). C. elegans has two subtypes of AChRs at the NMJ that are differentially sensitive to these agonists (Richmond and Jorgensen, 1999). The AChR subunits responsible for levamisole-triggered currents are UNC-38, UNC-63, UNC-29, and LEV-1 (Fleming et al., 1997; Culetto and Sattelle, 2000). On the other hand, ACR-16 is the only reported AChR subunit responsible and essential for nicotine-triggered currents, and it is insensitive to levamisole (Francis et al., 2005; Touroutine et al., 2005). These drugs generate a sustained stimulation of AChRs and release of $\mathrm{Ca}^{2+}$, causing paralysis in the worms. The time course of paralysis is dependent on the efficacy of synaptic transmission (Gottschalk et al., 2005; Mahoney et al., 2006).

The $C$. elegans transgenic worms that constitutively express the $\mathrm{A} \beta$ peptide in muscle cells and control worms (72 h of age) were assayed on NGM plates supplemented with one of the drugs mentioned above, and the course of paralysis was plotted. We did not find significant differences between the A $\beta$ transgenic C. elegans strain and its control when we assayed them on levamisole plates (Fig. 1A). However, we observed significant resistance to nicotine in the $\mathrm{A} \beta$ transgenic strain compared with its control (Fig. $1 \mathrm{~B}$ ). Resistance is also observed in assays using lower nicotine concentrations (20 and $25 \mathrm{~mm}$ ) (Fig. $1 F$ and data not shown). Older worms ( $120 \mathrm{~h}$ of age) also show the same response to levamisole and nicotine (Fig. 1C,D). These data suggest that not all postsynaptic AChRs are affected in this model; only those sensitive to nicotine but insensitive to levamisole appear to be compromised by the presence of $\mathrm{A} \beta$.

To support the idea that $A \beta$ is affecting the nicotine-sensitive receptors, we performed a genetic test. The acr-16 mutants do not show obvious locomotory defects on agar plates, whereas the levamisole receptor (unc-38, unc-63, unc-29 or lev-1) mutants show uncoordinated movement. The acr-16/unc-29 (or unc-38) double mutant has a synthetic phenotype where the uncoordinated movement is exacerbated (Francis et al., 2005). If $A \beta$ was interfering with ACR-16 but not with the levamisole (UNC-29containing) receptor, the uncoordinated phenotype of unc-29 mutants would be intensified with $\mathrm{A} \beta$ expression. Using thrashing assays, we observed that the expression of $A \beta$ increases the severity of the uncoordinated phenotype of unc-29(e193) mutants (Fig. $1 E$ ). This result suggests that the $\mathrm{A} \beta$ peptide is affecting molecules different from the AChRs sensitive to levamisole. Using the same strategy, we found that the $\mathrm{A} \beta$ worms are not statistically different from the $\mathrm{A} \beta$ worms in the acr-16 back-
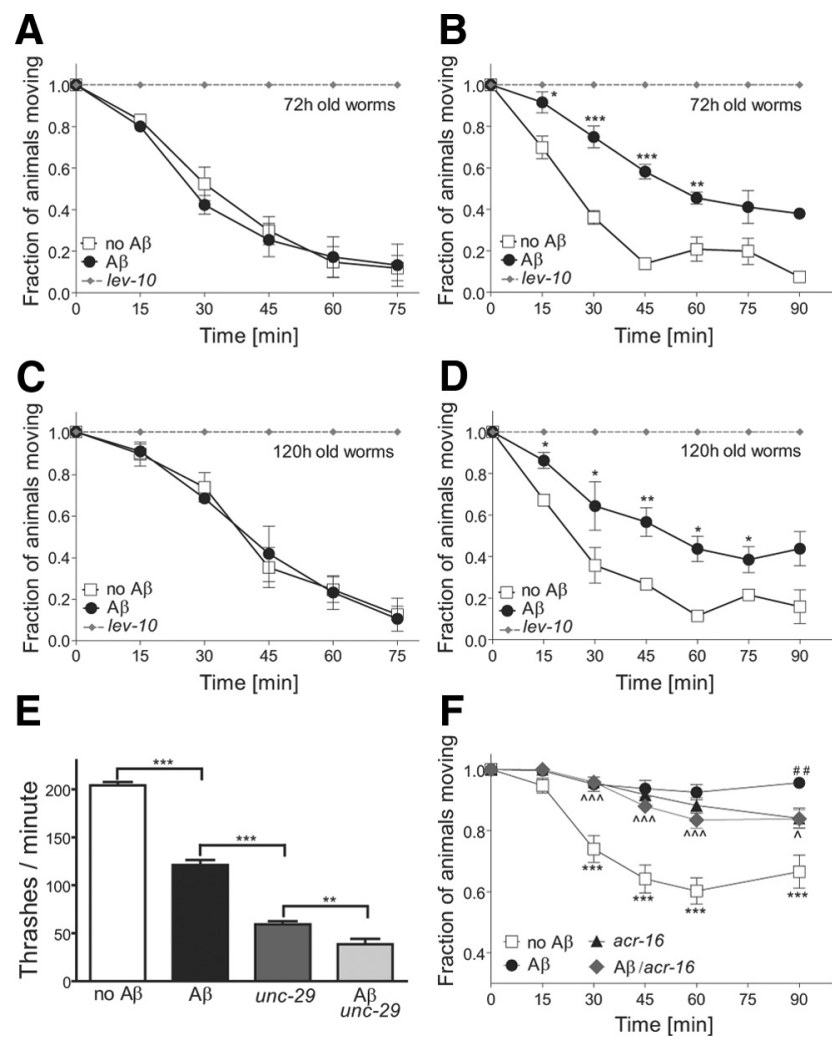

Figure 1. The expression of $A \beta$ in transgenic worms affects $A C h R$ sensitivity to nicotine but not to levamisole. $A-D, A \beta$ transgenic $C$. elegans strain $C L 2120$ and its control were cultured under regular conditions for $72 \mathrm{~h}(\boldsymbol{A}, \boldsymbol{B})$ or $120 \mathrm{~h}(\boldsymbol{C}, \boldsymbol{D})$ and exposed to $A C h R s$ agonists. The time course of paralysis in response to $0.25 \mathrm{~mm}$ levamisole $(\boldsymbol{A}, \boldsymbol{C})$ shows no significant differences between both strains. The paralysis time course in response to nicotine $(31 \mathrm{~mm})(\boldsymbol{B}, \boldsymbol{D})$ indicates significant resistance to nicotine in the $A \beta$ transgenic strain compared with the control. Each graph is the result of four independent experiments. The lev-10(ok1154) mutant known to be completely resistant to levamisole and nicotine was used as an internal control in all experiments. $\boldsymbol{E}$, Quantification of movement in liquid medium of $A \beta$ transgenics and of worms that express $A \beta$ in an unc- 29 mutant background. The presence of $A \beta$ aggravates the strong motility impairments of the unc-29 mutant worms. $\boldsymbol{F}$, Paralysis time course in response to nicotine (20 mm). The $\mathrm{A} \beta ;$; $a \mathrm{cr}-16$ strain shows a behavior similar to the $A \beta$ and $a c r-16$ strains. The graph is the result from at least five independent experiments. Differences are statistically significant: ${ }^{*} p=0.05,{ }^{* *} p=0.01,{ }^{* *} p=0.001$, comparing worms expressing $A \beta$ versus controls (no $A \beta$ ); $\wedge p=0.05, \wedge \wedge p=0.001$, comparing controls versus acr- 16 worms; $\# p=0.01$, comparing $A \beta$ versus $A \beta / a c r-16$ worms.

ground $(\mathrm{A} \beta, 107.8 \pm 3.9$ thrashes/min; $a c r-16 / \mathrm{A} \beta, 97.79 \pm 2.8$ thrashes/min; $p=0.0513)$, suggesting that ACR-16 may be one of the $\mathrm{A} \beta$ targets. We also performed nicotine sensitivity assays (20 $\mathrm{mm}$ ) (Fig. $1 \mathrm{~F}$ ). The acr-16 worms are resistant to $20 \mathrm{~mm}$ nicotine. We observed that, as we describe above, the worms that express $\mathrm{A} \beta$ are resistant to paralysis compared with control (no $\mathrm{A} \beta$ ) worms. If $\mathrm{A} \beta$ was affecting the ACR-16-containing receptors, worms expressing $\mathrm{A} \beta$ in the acr-16 background should have a phenotype very similar to that of the $A \beta$ worms. $A \beta$ and $A \beta /$ acr-16 worms show paralysis curves that are not statistically different at this nicotine concentration $(20 \mathrm{~mm})$, except for the last point of the curve ( $90 \mathrm{~min}$ ), where the $\mathrm{A} \beta /$ acr- 16 worms show improved synaptic transmission. This behavioral improvement of $A \beta$ worms in the absence of ACR-16 may indicate that ACR-16 is indeed one of the $\mathrm{A} \beta$ targets (direct or indirect) since its presence seems to be necessary for $\mathrm{A} \beta$ to exert full synaptic dysfunction. 

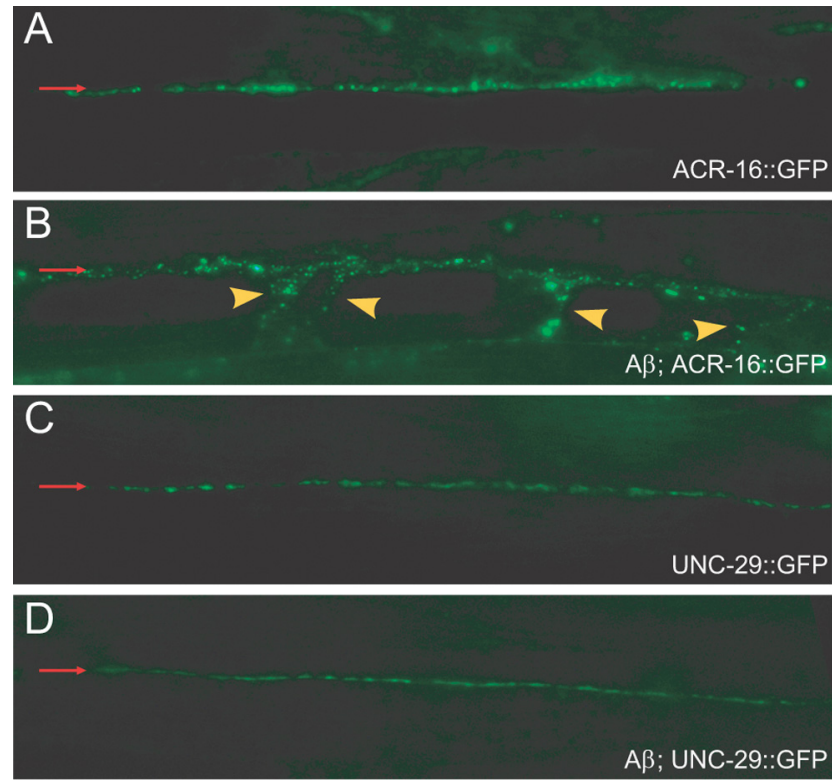

Figure 2. $A C R-16$-contaning $A C h R s$ are mislocalized in transgenic C. elegans expressing $A \beta$. $A$, Control worms (no $A \beta$ ) expressing ACR-16::GFP show fluorescent puncta over the ventral nerve cord (red arrows). $\boldsymbol{B}$, Worms that express $A \beta$ show a markedly altered localization of ACR-16::GFP puncta that can be seen in several muscle arms (arrowheads). Mislocalized ACR-16::GFP in muscle arms are as follows: no $A \beta, 28.57 \%(n=70) ; A \beta, 82.22 \%(n=90)$; $p<0.001$. C, Control worms (no $A \beta$ ) expressing UNC-29::GFP show fluorescent puncta over the ventral nerve cord. $\boldsymbol{D}$, The expression of $A \beta$ peptide does not alter the localization of UNC-29::GFP. Mislocalized UNC-29::GFP in muscle arms are as follows: $n 0 A \beta, 5.56 \%(n=36)$; $\mathrm{A} \beta, 3.78 \%(n=53) ; p=0.901$.

\section{The ACR-16 nicotinic acetylcholine receptor is mislocalized in $\mathrm{A} \beta$ transgenic $C$. elegans}

Since we found that $C$. elegans expressing $\mathrm{A} \beta$ have decreased sensitivity to nicotine compared with the control, we hypothesized that $\mathrm{A} \beta$ could be downmodulating the activity of ACR-16containing receptors, which could explain, in part, the nicotine resistance. One possible mechanism is that the presence of $A \beta$ could be directly or indirectly altering the subcellular localization of ACR-16 receptors. To test this possibility, we crossed the A $\beta$ expressing strain with a strain carrying ACR-16::GFP or UNC-29::GFP fusion proteins in muscle cells, and we analyzed the distribution of the fluorescent marker on the ventral nerve cord. Control worms expressing these markers show a punctuate pattern over the ventral nerve cord (Fig. $2 A, C$ ). $\mathrm{A} \beta$ expression does not change nerve cord localization of the UNC-29 subunit of the levamisole-sensitive receptors (Fig. 2D). In contrast, ACR-16::GFP localization is conspicuously altered in worms that express the $\mathrm{A} \beta$ peptide. We observe a less structured punctuate pattern over the ventral nerve cord and accumulation of fluorescent puncta in the muscle arms (Fig. 2B). In fact, the muscle arms can now be clearly observed because of the presence of the fluorescent-tagged receptors. The correct localization of the receptors at the nerve cord makes it virtually impossible to clearly visualize the muscle arms.

\section{Copper treatment improves synaptic function in $\mathrm{A} \beta$ transgenic worms}

We previously reported that copper treatment increases the number and size of amyloid deposits in this model (Minniti et al., 2009). At the time, we also showed some data that hinted at the possibility of copper being able to ameliorate the motility impairments in $\mathrm{A} \beta$ transgenic C. elegans. Here, we clearly show that copper treatment improves motility in $\mathrm{A} \beta$ transgenic worms at all ages tested (Fig. $3 A$ ).
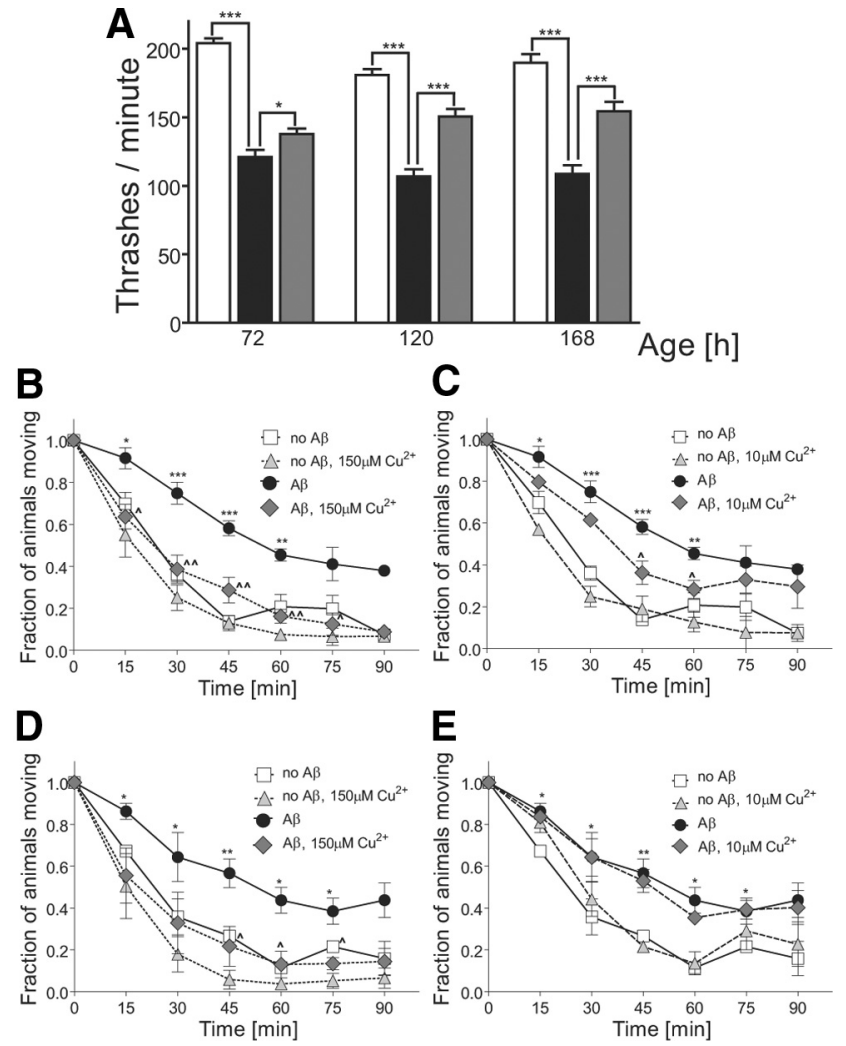

Figure 3. Copper treatment improves motility and NMJ function in $A \beta$ transgenic worms. $A$ $A \beta$ transgenic worms and controls (strains CL2120 and CL2122, respectively) were cultured in the presence or absence of $150 \mu \mathrm{M} \mathrm{CuCl}{ }_{2}$ and assayed for motility in liquid medium (thrashing) at different ages. Under normal culture conditions, the transgenic worms (black bars) move slower than the controls (white bars). Copper treatment is able to recover motility (gray bars). $n=20-40$ per bar. $\boldsymbol{B}, \boldsymbol{C}, A \beta$ transgenic worms and controls (CL2120 and CL2122 strains, respectively) were cultured in the presence or absence of $150 \mu \mathrm{m} \mathrm{CuCl}(B)$ or $10 \mu \mathrm{m} \mathrm{CuCl}(C)$, and assayed on nicotine plates at $72 \mathrm{~h}$ of age. The treatment partially recovered the normal response to nicotine when the $A \beta$ animals were cultured on $10 \mu$ m copper-supplemented plates $(\boldsymbol{C})$ and almost totally recovered the response to nicotine when they were cultured on $150 \mu \mathrm{m}$ coppersupplemented plates $(\boldsymbol{B}) \cdot \boldsymbol{D}, \boldsymbol{E}$, The same nicotine experiment was performed at $120 \mathrm{~h}$ of age. Only the $150 \mu \mathrm{m}$ copper $(\boldsymbol{D})$ treatment recovers thenormal response to nicotine of $A \beta$ transgenic worms at this age. Each graph is the result of four independent experiments. Comparing $A \beta$ transgenic worms with controls that donot express $A \beta$ : ${ }^{*} p=0.05,{ }^{* *} p=0.01,{ }^{* * *} p=0.001$; comparing the untreated and copper-treated $A \beta$ transgenic strain: $\wedge_{p}=0.05, \wedge_{p}=0.01$.

Therefore, we evaluated whether synaptic dysfunction and therefore nicotine resistance could also be prevented when the animals were cultured on $150 \mu \mathrm{M}$ copper-supplemented plates for $72 \mathrm{~h}$. The treatment was able to recover the normal response to nicotine in $\mathrm{A} \beta$ transgenic strains, resulting in a curve very similar to that of the control strain under regular culture conditions (Fig. 3B). Using a lower concentration of copper $(10 \mu \mathrm{M})$, the normal response is only partially recovered in 72-h-old worms (Fig. 3C). Once again, a similar behavior was observed in older worms $(120 \mathrm{~h})$ treated with 150 $\mu \mathrm{M}$ copper (Fig. $3 D$ ). However, treatment with $10 \mu \mathrm{M}$ copper did not improve behavior at this age (Fig. 3E). The response of the control strain (no $\mathrm{A} \beta$ ) to nicotine was not affected by copper treatment (Fig. $3 B-E)$, indicating that copper does not normally affect NMJ function at the concentrations we used.

Mislocalization of the nicotinic acetylcholine receptor ACR16 is prevented by copper treatment in $A \beta$ transgenic worms Since in our functional experiments we observed improved synaptic function after copper treatment, we decided to test whether this enhanced function correlates with a more correct localiza- 

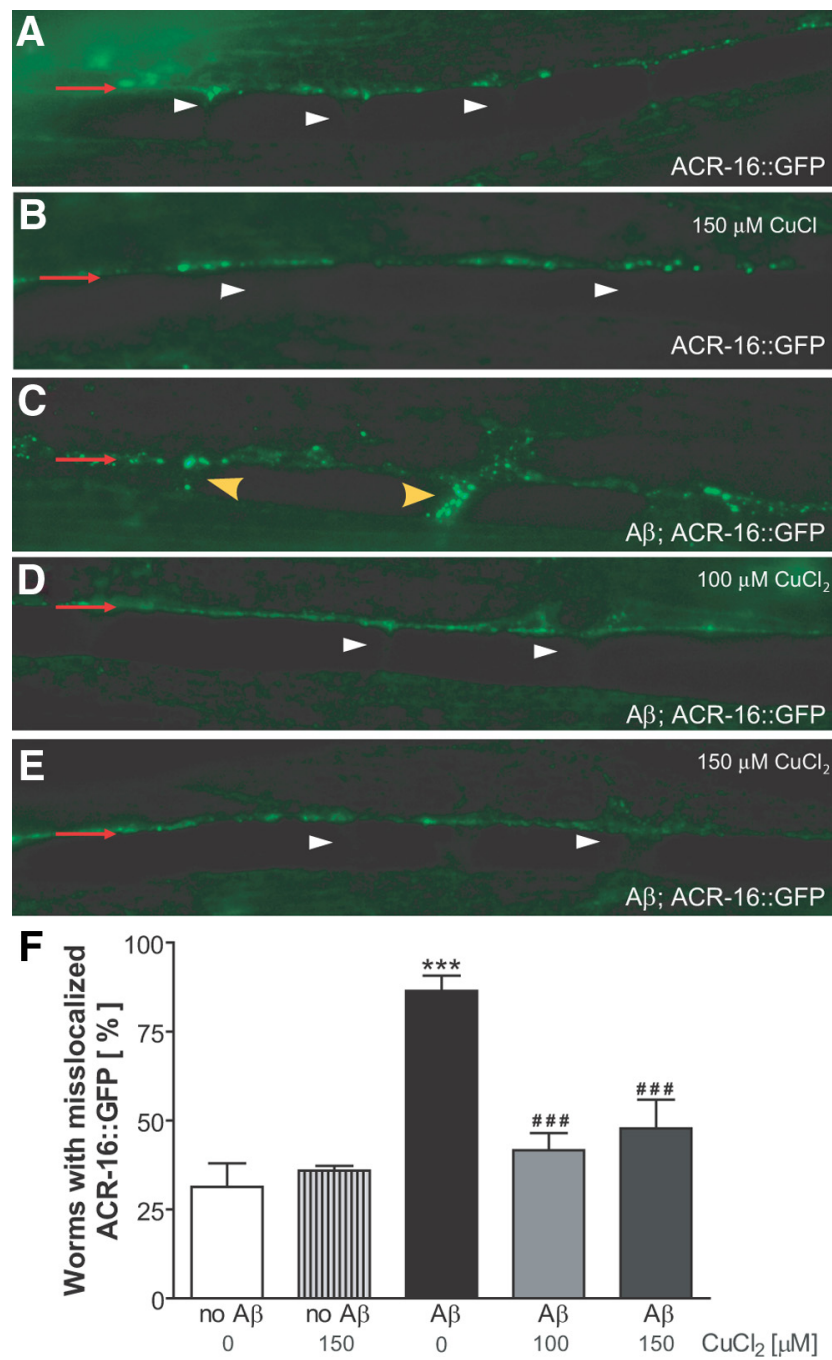

Figure 4. Copper treatment prevents mislocalization of $A C R-16:: G F P$ in $A \beta$ transgenic worms. $A$, Normal distribution of ACR-16 on the ventral nerve cord (red arrow) in control worms that do not express $A \beta$ in muscle cells. Note the absence of $A C R-16$ puncta in the muscle arms (arrowheads). $B$, The distribution of ACR-16::GFP is not altered when the worms were treated with copper. $C$, Abnormal ACR-16 puncta in the muscle arms (arrowheads) of $A \beta$ transgenic worms. $\boldsymbol{D}, \boldsymbol{E}, A \beta$ transgenic worms were treated with 100 or $150 \mu \mathrm{M} \mathrm{CuCl}$ for $72 \mathrm{~h}$ from the embryo stage. The localization of ACR-16::GFP in these worms appears similar to that of the control worms that do not express $A \beta(\boldsymbol{A})$. Red arrows, Nerve cord; arrowheads, muscle arms. $\boldsymbol{F}$, Quantification of the percentage of worms that have one or more muscle arms with mislocalized ACR-16::GFP, in three independent experiments. Control worms, $n=70$; control worms treated with $150 \mu \mathrm{m}$ copper, $n=70 ; A \beta$-expressing worms, $n=90 ; A \beta$-expressing worms treated with $100 \mu \mathrm{m}$ copper, $n=128 ; A \beta$-expressing worms treated with $150 \mu \mathrm{m}$ copper, $n=$ 127. ${ }^{* *} p=0.001$ : comparing $A \beta$ transgenic worms with the controls that do not express $A \beta$. $\#$ \#\#\# 0.001: comparing the untreated with the copper-treated $A \beta$ transgenic strain.

tion of the ACR-16 receptor. We analyzed the distribution of ACR-16::GFP on the ventral nerve cord in controls, $A \beta$ transgenics, and $\mathrm{A} \beta$ transgenics treated with copper for $72 \mathrm{~h}$ ( $1 \mathrm{~d}$ old $)$. We found that the altered localization of ACR-16::GFP observed in the $\mathrm{A} \beta$ transgenic worms (that extends to the muscle arms and away from NMJ contacts at the nerve cord) (Figs. $2 B, 4 C$ ) is reverted after copper treatment (Fig. $4 D, E$ ).

We quantified the percentage of worms with one or more muscle arms containing mislocalized ACR-16::GFP in five groups (control worms, control worms treated with copper, $\mathrm{A} \beta$ expressing worms, and $\mathrm{A} \beta$ transgenics treated with two concentrations of copper). The quantification shows that the presence of
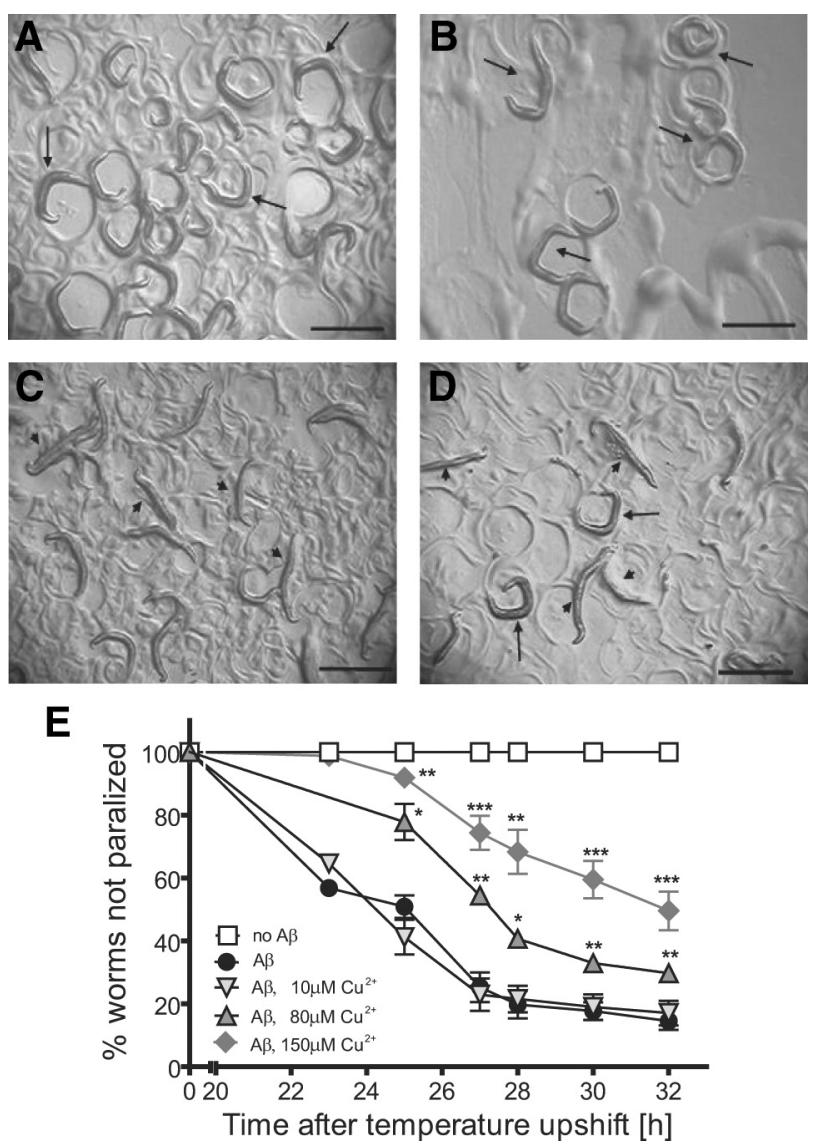

Figure 5. Copper treatment delays $A \beta$-induced paralysis in a temperature inducible strain. Temperature-inducible $A \beta$ transgenic worms and their control (strains CL4176 and CL802, respectively) were cultured on $N G M$ plates at $16^{\circ} \mathrm{C}$ until the $\mathrm{L} 3$ stage. They were then transferred to NGM plates supplemented with $\mathrm{CuCl}_{2}$, and the temperature was upshifted to $23^{\circ} \mathrm{C}$ to induce $A \beta$ expression ( $90-120$ worms per plate). $\boldsymbol{A}-\boldsymbol{D}$, Pictures show the transgenic worms on culture plates $30 \mathrm{~h}$ after temperature upshift. $\boldsymbol{A}$, The control strain (no $A \beta$ ) continues moving normally (arrows). $\boldsymbol{B}$, Inducible $A \beta$ transgenic worms move normally when they are kept at $16^{\circ} \mathrm{C}(\mathrm{ar}-$ rows). $C$, Temperature upshift to $23^{\circ} \mathrm{C}$ causes paralysis of $A \beta$ transgenic worms (short arrows) D, Temperature upshift to $23^{\circ} \mathrm{C}$ and copper exposure (150 $\mu \mathrm{m}$, in this case) increases the number of worms that continue moving (arrows). Scale bars, $1 \mathrm{~mm}$. $E$, The graph is the result of six independent experiments and shows that the progression of $A \beta$-induced paralysis in the transgenic worms is delayed by copper treatment in a concentration-dependent manner. ${ }^{*} p=0.05$, ${ }^{* *} p=0.01, p=0.001$ : comparing the untreated and copper-treated $A \beta$ transgenic strain.

$\mathrm{A} \beta$ significantly increases ACR-16 mislocalization and that this mislocalization is prevented by copper treatment (Fig. $4 F$ ). Control worms that express ACR-16::GFP show no altered receptor distribution in the presence of copper (Fig. $4 B$ ), whereas the expression of the GFP-tagged protein, evaluated by Western blot, seems to be unaltered by copper treatment (data not shown).

\section{Copper treatment delays $\mathrm{A} \boldsymbol{\beta}$-induced paralysis in a temperature-sensitive strain}

To further evaluate the effect of copper treatment on $\mathrm{A} \beta$-induced pathology, we used a temperature-sensitive $C$. elegans strain that expresses $\mathrm{A} \beta$ in muscle cells. The temperature upshift from 16 to $23^{\circ} \mathrm{C}$ during some larval stages induces abundant $\mathrm{A} \beta$ peptide expression, leading to progressive paralysis (Link et al., 2003). Representative pictures of the culture plates are shown in Figure 5 . The control strain (no A $\beta$ peptide expression) moves normally at $16^{\circ} \mathrm{C}$, and temperature upshift to $23^{\circ} \mathrm{C}$ does not trigger any phenotypes (Fig. $5 A$ ). The $\mathrm{A} \beta$ transgenic worms maintain their mobility when cultured at $16^{\circ} \mathrm{C}$ (Fig. $5 B$ ); if there is a temperature 
shift to $23^{\circ} \mathrm{C}$ during the L3 stage, the worms become paralyzed (Fig. 5C). For this experiment, we started copper treatments at the same time of the temperature upshift to $23^{\circ} \mathrm{C}$, when $\mathrm{A} \beta$ expression was induced. We could not do it during the embryo stage because the worms (both controls and $\mathrm{A} \beta$ worms) did not grow properly or died before they were adults (data no shown). It is possible that the different genetic background of the worms we used in this assay (smg-1) makes the worms more sensitive to copper toxicity during this developmental stage. Under these conditions, the progression of paralysis was delayed compared with that of the untreated worms (Fig. $5 C, D, E$ ). We used different copper concentrations, and we observed that this effect is concentration dependent (Fig. 5E).

\section{The SKN-1 transcription factor is not required for copper protection}

It was recently reported that the induction of the SKN-1 pathway in response to treatment with coffee extract leads to protection in a C. elegans model of $A \beta$ toxicity (Dostal et al., 2010). C. elegans SKN-1 is the functional orthologue of the mammalian protein Nrf2 (nuclear factor-E2-related factor 2 ), controlling the induction of multiple genes involved in detoxification and antioxidant stress response (Kahn et al., 2008). Nrf2 activation has been suggested to be protective in several neurodegenerative conditions, including neurons exposed to $\mathrm{A} \beta$ and a mouse model of $\mathrm{AD}$ (Kanninen et al., 2008, 2009; Wruck et al., 2008). It was also suggested that Nrf2 induction can be modulated by copper (Calay et al., 2010; Wang et al., 2010; Simmons et al., 2011).

Therefore, we investigated whether the SKN-1 detoxification pathway could be involved in the copper protection we observe in this model. We found that copper, at the concentrations used in our assays, is not able to induce the Pgst-4::GFP reporter gene in C. elegans (Kell et al., 2007) (Fig. 6A), where gst-4 (glutathione $S$-transferase) is a downstream effector of the SKN-1 phase II detoxification pathway (Kahn et al., 2008). To determine whether loss of SKN-1 can decrease or block the protection given by copper exposure, transgenic C. elegans expressing A $\beta$ were fed with skn-1 RNAi (Dostal et al., 2010). The $\mathrm{A} \beta$-induced paralysis in the temperature-sensitive strain (CL4176) is still delayed by copper treatment when $s k n-1$ is knocked down (Fig. $6 B$ ). We also used the inducible $\mathrm{A} \beta$ strain that carries the $s k n-1$ loss-of-function allele zu67 (CL6180) and its control (CL6176) that carries the wild-type copy of the gene, because $s k n-1$ knockdown worms may still have residual $s k n-1$ gene product. Again, our data show that the paralysis delay induced by copper treatment is maintained in the absence of SKN-1 (Fig. 6C).

Since we are particularly interested in neuromuscular junction dysfunction caused by $\mathrm{A} \beta$ accumulation in muscle cells, we

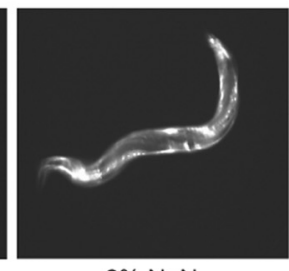

$2 \% \mathrm{NaN}_{3}$

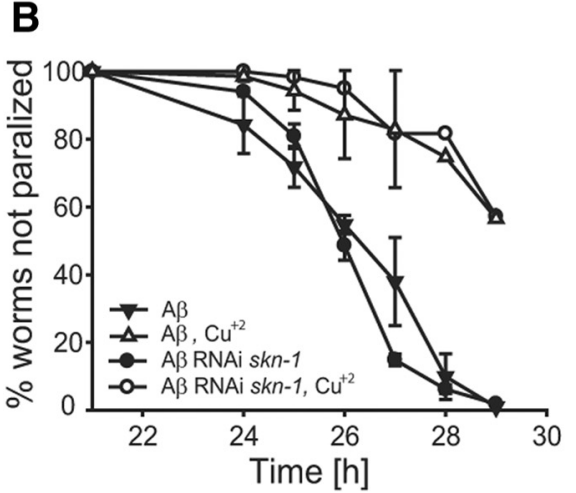

D

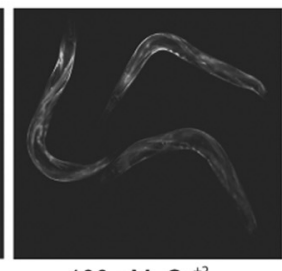

$100 \mu \mathrm{M} \mathrm{Cu}{ }^{+2}$

C

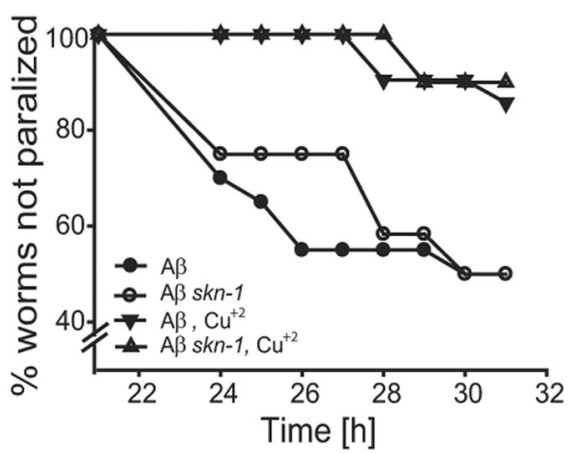

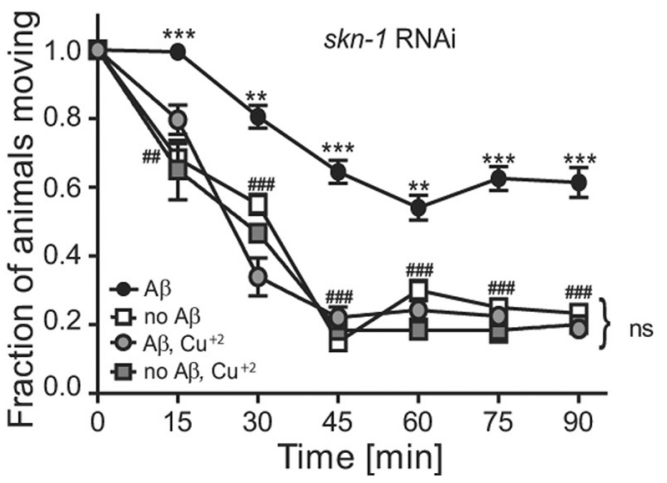

Figure 6. The SKN- 1 transcription factor is not required for copper protection. $A$, Induction of the Pgst-4::GFP reporter in strain CL6176 exposed to 100 and $150 \mu \mathrm{M} \mathrm{CuCl}$. Two percent $\mathrm{NaN}_{3}$ in Mg buffer is the positive control, leading to induction of the reporter. None of the (16) show that the paralysis delay induced by copper treatment is maintained in the absence of $\mathrm{KKN}-1$. Assays were performed . elegans strain CL2120 and its control CL2122 were fed with skn-1 RNAi and exposed to $31 \mathrm{~mm}$ nicotine for $90 \mathrm{~min}$. The norma

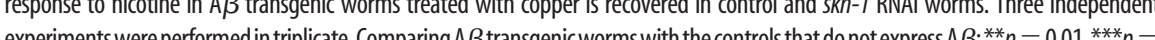
0.001. Comparing the untreated with the copper treated $A \beta$ transgenic strain: ${ }^{\# \#} p=0.01$, ${ }^{\# \#} p=0.001$. ns, Not significant.

performed nicotine assays to evaluate whether copper treatment could still improve synaptic function in the absence of SKN-1. The results show that knocking down $s k n-1$ using the RNAi feeding protocol does not block the effect of copper in recovering the normal response to nicotine in $A \beta$ transgenic worms (Fig. $6 D$ ). Note that the graph in Figure $6 D$ is equivalent to that shown in Figure $3 B$, where $s k n-1$ was not manipulated. Therefore, under the conditions of our experiments, the SKN-1 pathway (Nrf2 in mammals) does not appear to be involved in copper protection in this model of $\mathrm{A} \beta$ toxicity.

Copper treatment decreases the relative amounts of soluble $\mathrm{A} \boldsymbol{\beta}$ oligomers

In the $C$. elegans strain that constitutively expresses $\mathrm{A} \beta$, there is a correlation between copper treatment, increment of amyloid de- 
A
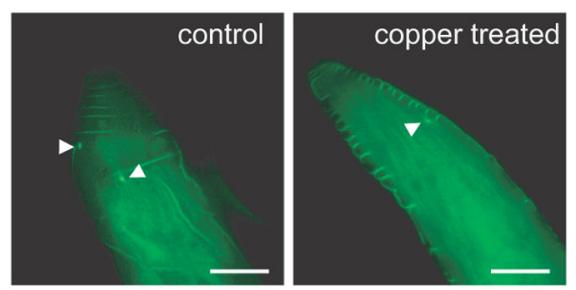

B

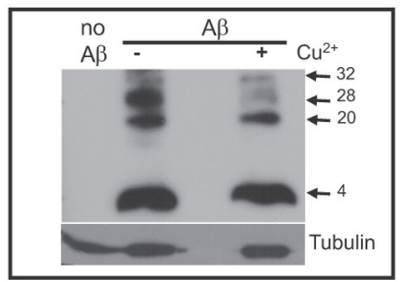

D

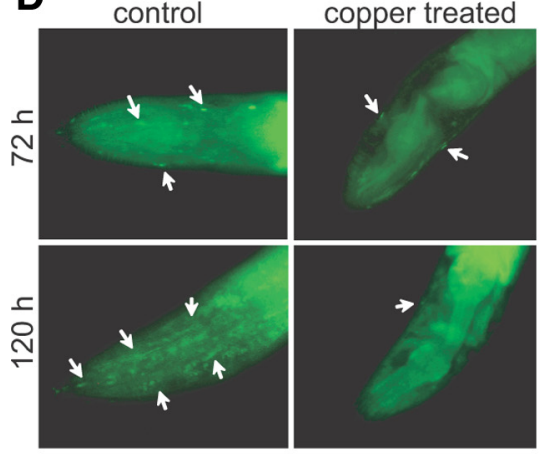

C

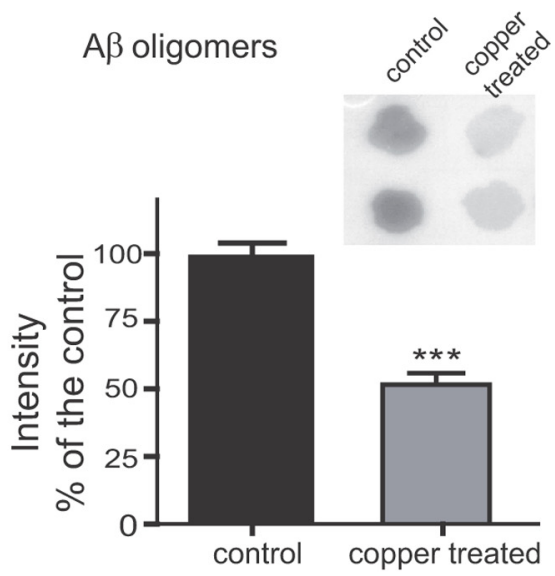

E

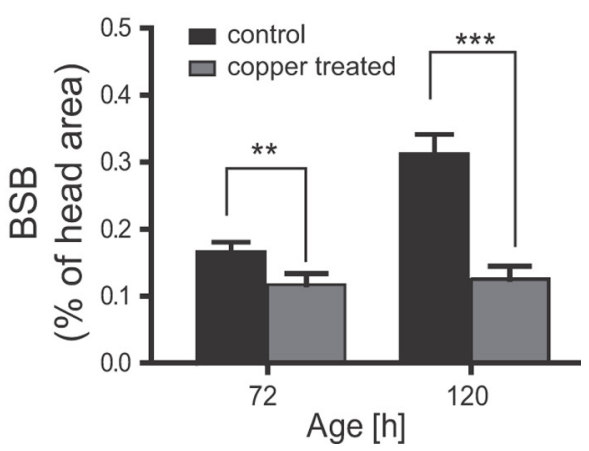

Figure 7. Copper treatment modulates the relative quantity of $A \beta$ species. $A$, Th-S staining of $A \beta$ temperature-inducible worms, cultured in the presence or absence of copper $30 \mathrm{~h}$ after temperature upshift to $23^{\circ} \mathrm{C}$. Very few Th-S-positive amyloid deposits were observed (arrowheads) and are not quantifiable. B, Western blots from temperature-sensitive strain CL4176. Bands of higher molecular weight decreased in intensity after copper treatment. A representative blot from four independent experiments is shown. C, Representative dot blot analysis from A $\beta$ transgenic strain CL2120 (constitutive $A \beta$ expression) that recognizes the oligomeric species. A significant reduction of intensity is observed in the samples from worms that had been treated with copper. The graph shows the quantification of the dot blots and is the result of three independent experiments. D, BSB staining of 72 and $120 \mathrm{~h}$ worms that express $A \beta$ constitutively. Arrows show BSB-positive areas. $E$, Quantification of BSB-positive areas in 72 and 120-h-old control (black bars) and copper-treated (gray bars) worms. The quantification of BSB was done in the head of at least 50 worms per experimental condition and in three independent experiments. ${ }^{* *} p=0.01,{ }^{* * *} p=0.001$.

posits (Minniti et al., 2009), improvement of motility, and recovery of a normal response to nicotine. In the temperatureinducible strain, copper treatment delays $\mathrm{A} \beta$-induced paralysis. To investigate whether there was also an increment of amyloid deposits in this temperature-sensitive strain, we tested the status of $A \beta$ aggregation in the temperature-sensitive strain by Th-S staining $30 \mathrm{~h}$ after temperature upshift. We were not able to observe quantifiable Th-S-positive deposits in either control or copper treatment conditions (Fig. 7A). It is likely that the time allowed for $A \beta$ induction is not enough for the formation of Th-S-positive amyloid aggregates. Longer induction times are not possible because the animals become paralyzed.

Because we were not able to observe amyloid deposits with Th-S, we performed Western blot analyses using the $6 \mathrm{E} 10$ antibody, which recognizes residues $1-17$ of $A \beta$, to determine the $A \beta$ species present in the $C$. elegans temperature-inducible strain. We were able to visualize four bands: the monomer $(\sim 4 \mathrm{kDa})$ and three oligomeric forms of 20,28 , and $32 \mathrm{kDa}$. This assay shows that the worms treated with $150 \mu \mathrm{M}$ copper have lower quantities of these oligomeric forms than the untreated worms, with no changes in the relative quantities of the monomer (Fig. 7B). Our results suggest that copper may induce a shift from $A \beta$ oligomeric species to less toxic fibrilar species that do not reach amyloid structure before the animal becomes paralyzed. Since immunoreactive bands from SDS-PAGE may not necessarily indicate the presence of oligomeric species in vivo (Bitan et al., 2005), we also used two other approaches to analyze the presence of $\mathrm{A} \beta$ oligomers.

We evaluated whether the increment in amyloid deposits observed in the strain that expresses $\mathrm{A} \beta$ constitutively correlates with a decrease in oligomeric forms of $A \beta$. We performed dot-blot assays in strain CL2120, using the A11 antibody that recognizes oligomeric species (Kayed et al., 2003). We observed that copper treatment $(150 \mu \mathrm{M})$ significantly decreased the amount of oligomers compared with the same untreated strains (Fig. 7C). We obtained similar results using strain CL2006 (data not shown). In addition, we stained the worms with the dye BSB, a Congo Red derivative that has higher affinity for oligomers than for fibrils (Schmidt et al., 2001; Maezawa et al., 2008; Toledo and Inestrosa, 2009). BSB-positive areas are decreased after copper treatment (Fig. $7 D, E)$, providing additional evidence for oligomeric species reduction.

\section{Discussion}

It is currently accepted that the $\mathrm{A} \beta$ peptide is the main player in $\mathrm{AD}$ and its effects are not limited to neuronal death in areas of $A \beta$ accumulation. Several early effects in $\mathrm{AD}$ development, leading to loss of synaptic function, have also been attributed to $\mathrm{A} \beta$ (Selkoe, 2002). For instance, AD murine models overexpressing $A \beta$ show an important decrease in immunoreactivity for synaptophysin (Mucke et al., 2000), which is also seen in AD patients (Masliah et al., 2001a,b). In addition, cellular cultures from IBM patient biopsies show evidence of abnormal innervations: NMJ proteins such as AChRs and acetylcholinesterase are diffusely distributed (McFerrin et al., 1998), suggesting a neuromuscular synaptic transmission disorder (Askanas et al., 1998). In our work, through pharmacological manipulation of synaptic transmission, we identified changes at the $C$. elegans NMJ attributable to $\mathrm{A} \beta$ expression, and we show that copper treatment can reverse these defects. We did not find copper upregulation of the SKN-1 phase II detoxification pathway, known to confer protection against $A \beta$ toxicity. On the other hand, the histological and biochemical assays suggest that protection is given by decreasing $A \beta$ oligomeric species. We found that $C$. elegans expressing $A \beta$ have decreased sensitivity to nicotine compared with the control. This is a new phenotype for $\mathrm{A} \beta$ transgenic strains used as models of AD and IBM. Since there is no difference in the response to levamisole, we hypothesize that there might be a selective effect of $\mathrm{A} \beta$ on the AChRs, affecting only those that are sensitive to nicotine but insensitive to levamisole. This is supported by the results showing mislocalization of 
ACR-16-containing AChRs, whereas UNC-29-containing receptors are not affected.

The sequence of the C. elegans ACR-16 protein, the only essential component of the AChR-mediated nicotinic current (Francis et al., 2005; Touroutine et al., 2005), shows high identity with the $\alpha 7$ subunit of the vertebrate nicotinic AChR (Ballivet et al., 1996). The vertebrate nicotinic AChRs (nAChRs) containing the $\alpha 7$ subunit are localized in several brain areas that are involved in cognitive function (Dominguez del Toro et al., 1994; Drago et al., 2003), and their abnormal functionality has been related to several neuropathologies, including $\mathrm{AD}$ (Quirion et al., 1986; Perry et al., 1987, 1995). For instance, $\alpha 7 \mathrm{nAChRs}$ colocalize with $\mathrm{AD}$ plaques (Wang et al., 2000a) and correlate with neurons that accumulate $A \beta$ (Wevers et al., 1999) and with neurons most vulnerable to $A \beta$ toxicity (D'Andrea and Nagele, 2006). Furthermore, there are data showing a likely $\mathrm{A} \beta / \alpha 7 \mathrm{nAChR}$ interaction (Wang et al., 2000a,b). However, the consequences of these interactions are a controversial issue: For instance, it was shown that the activity of $\alpha 7 \mathrm{nAChR}$ is blocked by $\mathrm{A} \beta$, supporting the hypothesis that $\mathrm{A} \beta$ could inactivate these receptors (Liu et al., $2001)$. On the other hand, other researchers showed that extracellular $\mathrm{A} \beta$ can selectively activate $\alpha 7 \mathrm{nAChRs}$ (Dineley et al., 2002). Nevertheless, the prolonged exposure to $A \beta$ leads to receptor inhibition, probably through desensitization. Additionally, the association of $\mathrm{A} \beta$ with $\alpha 7 \mathrm{nAChR}$ can trigger $\mathrm{A} \beta$ internalization, generating intracellular accumulation and, eventually, toxicity (Nagele et al., 2002); however, it is not clear whether this internalization is caused by an indirect influence or to a direct binding of $\mathrm{A} \beta$ to AChRs. Buckingham et al. (2009), summarized evidence showing that the signaling pathways affected by intracellular $A \beta$ accumulation seem to be the same as those intervened by extracellular $\mathrm{A} \beta$ treatment. The authors speculate that the activation of $\mathrm{nAChR}$-dependent pathways by exogenous $A \beta$ is actually the result of $A \beta$ internalization and discuss that the partial block of $\alpha 7 \mathrm{nAChR}$ responses by $\mathrm{A} \beta$ may be the result of $A \beta$-induced internalization of the receptors (Buckingham et al., 2009).

Given this background and our results showing that the expression of intracellular $A \beta$ peptide leads to mislocalization of ACR-16-containing AChRs (Fig. $2 B$ ), we speculate that an A $\beta$ / ACR-16 interaction could be altering the activity of ACR-16containing receptors, which could explain the partial nicotine resistance. However, we do not know when and where $A \beta$ could be interacting directly or indirectly with ACR-16. Studies from vertebrate $\alpha 7 \mathrm{nAChRs}$ have been performed incubating the cells with $A \beta$ solutions (Wang et al., 2000a,b), suggesting an interaction when the receptor is at the cell surface. However, the transgenic C. elegans strains express the $\mathrm{A} \beta$ peptide intracellularly in muscle cells (Link, 1995), as is the case of $A \beta$ accumulation in IBM (Askanas and Engel, 2007). The A $\beta$ - expressing strains used in this work were generated from a construct that contains a secretion signal sequence (Link, 1995) with the aim of obtaining a worm that could secrete high levels of $A \beta$ peptide. However, the strains obtained had detectable $A \beta$ levels only intracellularly, maybe because the short translation product of the minigene unc-54/A $\beta$ could interfere with an efficient traffic through the secretory pathway. Alternatively, amyloid deposition inside the muscle cells could prevent the secretion of immunologically detectable $A \beta$ (Link, 1995). In this scene, the interaction between ACR-16 and $A \beta$ peptide may occur either in the secretory pathway as well as on the cell surface with some undetectable secreted $\mathrm{A} \beta$. In our experiments, the ACR-16::GFP protein is found in the muscle arms, but we cannot distinguish whether this is a conse- quence of ACR-16 internalization or altered traffic to the postsynaptic site. Because of the reasons explained before, both alternatives are possible. Furthermore, although ACR-16 receptor mislocalization could be a mechanism for partially explaining the synaptic dysfunction observed in transgenic C. elegans, possible alterations in ionic channel properties of ACR-16, and also some other proteins involved in intracellular receptor trafficking, could occur because of the presence of $A \beta$. For instance, $A \beta$ could be interfering with the Ror-receptor tyrosine kinase CAM-1 that is required for ACR-16 localization to the postsynaptic region at the NMJ (CAM-1 is not involved in the localization of other receptors such us UNC-29 and UNC-49 (GABA receptors) (Francis et al., 2005).

We have previously shown that copper treatment increases both the number and area of amyloid deposits in the muscle cells of C. elegans expressing A $\beta$ (Minniti et al., 2009). This observation is consistent with in vitro data showing copper induced acceleration of $A \beta$ aggregation (Bush et al., 1994a,b). The intracellular amyloid deposits have been widely used as a pathological marker in C. elegans, and the reduction of these deposits has been considered beneficial in this model (Wu et al., 2006). However, our data suggest that the increased aggregation triggered by copper treatment actually improves behavioral deficits. Here, we show improved motility in liquid medium when transgenic $\mathrm{A} \beta$ worms are treated with $\mathrm{CuCl}_{2}$. The control strain, which does not express $\mathrm{A} \beta$, shows abnormal development, compromised motility, and a general unhealthy appearance when cultured at the same concentration of $\mathrm{CuCl}_{2}$, supporting the idea that $\mathrm{A} \beta$ expression and aggregation can confer resistance to copper toxicity (Minniti et al., 2009). Furthermore, $A \beta$-induced paralysis in the temperature-sensitive strain is delayed by copper treatment in a concentration-dependent manner. However, it is likely that treatments with higher concentrations of copper exceed the protective role of $A \beta$ and become harmful. Our results show that the protective effect of copper does not seem to be attributable to the activation of the SKN-1/Nrf2 phase II detoxification pathway, opposite to that found for coffee extract in this model (Dostal et al., 2010).

The improved motility in liquid medium and the delay in $\mathrm{A} \beta$-induced paralysis triggered by copper exposure associated with an increment in $\mathrm{A} \beta$ aggregation suggest that increased amyloidosis could be decreasing the quantity of oligomeric species considered to be the toxic species in AD (Cleary et al., 2005; Lesne et al., 2006; De Felice et al., 2007; Lacor et al., 2007; Cerpa et al., 2008). Furthermore, $A \beta$ oligomers are also present intracellularly in muscle fibers of IBM patients, where they could contribute to the pathogenic cascade (Nogalska et al., 2010). Our biochemical and histochemical analyses show strong evidence of $A \beta$ soluble oligomer reduction after copper treatment (Fig. 7).

In summary, we have shown a new phenotype in C. elegans that expresses $A \beta$ in muscle cells: NMJ defects manifested as resistance to nicotine that correlate with the mislocalization of ACR-16::GFP-containing receptors. We have also shown that copper can modulate $\mathrm{A} \beta$-induced synaptic dysfunction and altered morphology and delay the development of paralysis in this invertebrate IBM model. The increment in amyloid deposits triggered by copper and the associated decrease of some oligomeric $\mathrm{A} \beta$ species is related with the improvement of $\mathrm{A} \beta$-induced pathological traits. Our research suggests that neuromuscular synaptic dysfunction could be an important early feature of human IBM pathology and that the modulation of the amyloidogenic component in this disease could be a relevant therapeutic alternative. 


\section{References}

Askanas V, Engel WK (2006) Inclusion-body myositis: a myodegenerative conformational disorder associated with $\mathrm{A} \beta$, protein misfolding, and proteasome inhibition. Neurology 66:S39-S48.

Askanas V, Engel WK (2007) Inclusion-body myositis, a multifactorial muscle disease associated with aging: current concepts of pathogenesis. Curr Opin Rheumatol 19:550-559.

Askanas V, Engel WK, Alvarez RB (1998) Fourteen newly recognized proteins at the human neuromuscular junctions-and their nonjunctional accumulation in inclusion-body myositis. Ann N Y Acad Sci 841:28-56.

Ballivet M, Alliod C, Bertrand S, Bertrand D (1996) Nicotinic acetylcholine receptors in the nematode Caenorhabditis elegans. J Mol Biol 258: 261-269.

Barohn RJ, Herbelin L, Kissel JT, King W, McVey AL, Saperstein DS, Mendell JR (2006) Pilot trial of etanercept in the treatment of inclusion-body myositis. Neurology 66:S123-S124.

Bitan G, Fradinger EA, Spring SM, Teplow DB (2005) Neurotoxic protein oligomers - what you see is not always what you get. Amyloid 12:88-95.

Brenner S (1974) The genetics of Caenorhabditis elegans. Genetics 77:71-94.

Buckingham SD, Jones AK, Brown LA, Sattelle DB (2009) Nicotinic acetylcholine receptor signalling: roles in Alzheimer's disease and amyloid neuroprotection. Pharmacol Rev 61:39-61.

Bush AI, Pettingell WH Jr, Paradis MD, Tanzi RE (1994a) Modulation of $\mathrm{A} \beta$ adhesiveness and secretase site cleavage by zinc. J Biol Chem 269:12152-12158.

Bush AI, Pettingell WH, Multhaup G, d Paradis M, Vonsattel JP, Gusella JF, Beyreuther K, Masters CL, Tanzi RE (1994b) Rapid induction of Alzheimer A $\beta$ amyloid formation by zinc. Science 265:1464-1467.

Calay D, Rousseau A, Mattart L, Nuyens V, Delporte C, Van Antwerpen P, Moguilevsky N, Arnould T, Boudjeltia KZ, Raes M (2010) Copper and myeloperoxidase-modified LDLs activate Nrf2 through different pathways of ROS production in macrophages. Antioxid Redox Signal 13:1491-1502.

Cerpa W, Varela-Nallar L, Reyes AE, Minniti AN, Inestrosa NC (2005) Is there a role for copper in neurodegenerative diseases? Mol Aspects Med 26:405-420.

Cerpa W, Dinamarca MC, Inestrosa NC (2008) Structure-function implications in Alzheimer's disease: effect of $A \beta$ oligomers at central synapses. Curr Alzheimer Res 5:233-243.

Cherny RA, Atwood CS, Xilinas ME, Gray DN, Jones WD, McLean CA, Barnham KJ, Volitakis I, Fraser FW, Kim Y, Huang X, Goldstein LE, Moir RD, Lim JT, Beyreuther K, Zheng H, Tanzi RE, Masters CL, Bush AI (2001) Treatment with a copper-zinc chelator markedly and rapidly inhibits $\beta$-amyloid accumulation in Alzheimer's disease transgenic mice. Neuron 30:665-676.

Cleary JP, Walsh DM, Hofmeister JJ, Shankar GM, Kuskowski MA, Selkoe DJ, Ashe KH (2005) Natural oligomers of the amyloid- $\beta$ protein specifically disrupt cognitive function. Nat Neurosci 8:79-84.

Culetto E, Sattelle DB (2000) A role for Caenorhabditis elegans in understanding the function and interactions of human disease genes. Hum Mol Genet 9:869-877.

Dalakas MC, Koffman B, Fujii M, Spector S, Sivakumar K, Cupler E (2001) A controlled study of intravenous immunoglobulin combined with prednisone in the treatment of IBM. Neurology 56:323-327.

D'Andrea MR, Nagele RG (2006) Targeting the $\alpha 7$ nicotinic acetylcholine receptor to reduce amyloid accumulation in Alzheimer's disease pyramidal neurons. Curr Pharm Des 12:677-684.

De Felice FG, Velasco PT, Lambert MP, Viola K, Fernandez SJ, Ferreira ST, Klein WL (2007) $A \beta$ oligomers induce neuronal oxidative stress through an $\mathrm{N}$-methyl-D-aspartate receptor-dependent mechanism that is blocked by the Alzheimer drug memantine. J Biol Chem 282:11590-11601.

Dineley KT, Bell KA, Bui D, Sweatt JD (2002) $\beta$-Amyloid peptide activates $\alpha 7$ nicotinic acetylcholine receptors expressed in Xenopus oocytes. J Biol Chem 277:25056-25061.

Dominguez del Toro E, Juiz JM, Peng X, Lindstrom J, Criado M (1994) Immunocytochemical localization of the $\alpha 7$ subunit of the nicotinic acetylcholine receptor in the rat central nervous system. J Comp Neurol 349:325-342.

Dosanjh LE, Brown MK, Rao G, Link CD, Luo Y (2010) Behavioral phenotyping of a transgenic Caenorhabditis elegans expressing neuronal amyloid- $\beta$. J Alzheimers Dis 19:681-690.
Dostal V, Roberts CM, Link CD (2010) Genetic mechanisms of coffee extract protection in a Caenorhabditis elegans model of $\beta$-amyloid peptide toxicity. Genetics 186:857-866.

Drago J, McColl CD, Horne MK, Finkelstein DI, Ross SA (2003) Neuronal nicotinic receptors: insights gained from gene knockout and knockin mutant mice. Cell Mol Life Sci 60:1267-1280.

Fay DS, Fluet A, Johnson CJ, Link CD (1998) In vivo aggregation of $\beta$-amyloid peptide variants. J Neurochem 71:1616-1625.

Fleming JT, Squire MD, Barnes TM, Tornoe C, Matsuda K, Ahnn J, Fire A, Sulston JE, Barnard EA, Sattelle DB, Lewis JA (1997) Caenorhabditis elegans levamisole resistance genes lev-1, unc-29, and unc-38 encode functional nicotinic acetylcholine receptor subunits. J Neurosci 17: 5843-5857.

Francis MM, Evans SP, Jensen M, Madsen DM, Mancuso J, Norman KR, Maricq AV (2005) The Ror receptor tyrosine kinase CAM-1 is required for ACR-16-mediated synaptic transmission at the C. elegans neuromuscular junction. Neuron 46:581-594.

Gally C, Eimer S, Richmond JE, Bessereau JL (2004) A transmembrane protein required for acetylcholine receptor clustering in Caenorhabditis elegans. Nature 431:578-582.

Gottschalk A, Almedom RB, Schedletzky T, Anderson SD, Yates JR 3rd, Schafer WR (2005) Identification and characterization of novel nicotinic receptor-associated proteins in Caenorhabditis elegans. EMBO J 24:2566-2578.

Kahn NW, Rea SL, Moyle S, Kell A, Johnson TE (2008) Proteasomal dysfunction activates the transcription factor $\mathrm{SKN}-1$ and produces a selective oxidative-stress response in Caenorhabditis elegans. Biochem J 409:205-213.

Kanninen K, Malm TM, Jyrkkanen HK, Goldsteins G, Keksa-Goldsteine V, Tanila H, Yamamoto M, Yla-Herttuala S, Levonen AL, Koistinaho J (2008) Nuclear factor erythroid 2-related factor 2 protects against $\beta$-amyloid. Mol Cell Neurosci 39:302-313.

Kanninen K, Heikkinen R, Malm T, Rolova T, Kuhmonen S, Leinonen H, Yla-Herttuala S, Tanila H, Levonen AL, Koistinaho M, Koistinaho J (2009) Intrahippocampal injection of a lentiviral vector expressing Nrf2 improves spatial learning in a mouse model of Alzheimer's disease. Proc Natl Acad Sci U S A 106:16505-16510.

Kayed R, Head E, Thompson JL, McIntire TM, Milton SC, Cotman CW, Glabe CG (2003) Common structure of soluble amyloid oligomers implies common mechanism of pathogenesis. Science 300:486-489.

Kell A, Ventura N, Kahn N, Johnson TE (2007) Activation of SKN-1 by novel kinases in Caenorhabditis elegans. Free Radic Biol Med 43:1560-1566.

Kessler H, Pajonk FG, Supprian T, Falkai P, Multhaup G, Bayer TA (2005) [The role of copper in the pathophysiology of Alzheimer's disease]. Nervenarzt 76:581-585.

Lacor PN, Buniel MC, Furlow PW, Clemente AS, Velasco PT, Wood M, Viola KL, Klein WL (2007) A $\beta$ oligomer-induced aberrations in synapse composition, shape, and density provide a molecular basis for loss of connectivity in Alzheimer's disease. J Neurosci 27:796-807.

Lesne S, Koh MT, Kotilinek L, Kayed R, Glabe CG, Yang A, Gallagher M, Ashe $\mathrm{KH}$ (2006) A specific amyloid- $\beta$ protein assembly in the brain impairs memory. Nature 440:352-357.

Lewis JA, Fleming JT (1995) Basic culture methods. Methods Cell Biol 48:3-29.

Link CD (1995) Expression of human $\beta$-amyloid peptide in transgenic Caenorhabditis elegans. Proc Natl Acad Sci U S A 92:9368-9372.

Link CD, Taft A, Kapulkin V, Duke K, Kim S, Fei Q, Wood DE, Sahagan BG (2003) Gene expression analysis in a transgenic Caenorhabditis elegans Alzheimer's disease model. Neurobiol Aging 24:397-413.

Liu Q, Kawai H, Berg DK (2001) $\beta$-Amyloid peptide blocks the response of $\alpha 7$-containing nicotinic receptors on hippocampal neurons. Proc Natl Acad Sci U S A 98:4734-4739.

Lovell MA, Robertson JD, Teesdale WJ, Campbell JL, Markesbery WR (1998) Copper, iron and zinc in Alzheimer's disease senile plaques. J Neurol Sci 158:47-52.

Maezawa I, Hong HS, Liu R, Wu CY, Cheng RH, Kung MP, Kung HF, Lam KS, Oddo S, Laferla FM, Jin LW (2008) Congo red and thioflavin-T analogs detect $A \beta$ oligomers. J Neurochem 104:457-468.

Mahoney TR, Luo S, Nonet ML (2006) Analysis of synaptic transmission in Caenorhabditis elegans using an aldicarb-sensitivity assay. Nat Protoc 1:1772-1777. 
Masliah E, Mallory M, Alford M, DeTeresa R, Hansen LA, McKeel DW Jr, Morris JC (2001a) Altered expression of synaptic proteins occurs early during progression of Alzheimer's disease. Neurology 56:127-129.

Masliah E, Alford M, Galasko D, Salmon D, Hansen LA, Good PF, Perl DP, Thal L (2001b) Cholinergic deficits in the brains of patients with parkinsonism-dementia complex of Guam. Neuroreport 12:3901-3903.

Masters CL, Multhaup G, Simms G, Pottgiesser J, Martins RN, Beyreuther K (1985) Neuronal origin of a cerebral amyloid: neurofibrillary tangles of Alzheimer's disease contain the same protein as the amyloid of plaque cores and blood vessels. EMBO J 4:2757-2763.

McColl G, Roberts BR, Gunn AP, Perez KA, Tew DJ, Masters CL, Barnham KJ, Cherny RA, Bush AI (2009) The Caenorhabditis elegans $A \beta_{1-42}$ model of Alzheimer disease predominantly expresses $\mathrm{A} \beta_{3-42}$. J Biol Chem 284:22697-22702.

McFerrin J, Engel WK, Askanas V (1998) Impaired innervation of cultured human muscle overexpressing $\beta$ APP experimentally and genetically: relevance to inclusion-body myopathies. Neuroreport 9:3201-3205.

Miller KG, Alfonso A, Nguyen M, Crowell JA, Johnson CD, Rand JB (1996) A genetic selection for Caenorhabditis elegans synaptic transmission mutants. Proc Natl Acad Sci U S A 93:12593-12598.

Minniti AN, Rebolledo DL, Grez PM, Fadic R, Aldunate R, Volitakis I, Cherny RA, Opazo C, Masters C, Bush AI, Inestrosa NC (2009) Intracellular amyloid formation in muscle cells of $\mathrm{A} \beta$-transgenic Caenorhabditis elegans: determinants and physiological role in copper detoxification. Mol Neurodegener 4:2.

Mucke L, Masliah E, Yu GQ, Mallory M, Rockenstein EM, Tatsuno G, Hu K, Kholodenko D, Johnson-Wood K, McConlogue L (2000) High-level neuronal expression of $\mathrm{A} \beta_{1-42}$ in wild-type human amyloid protein precursor transgenic mice: synaptotoxicity without plaque formation. J Neurosci 20:4050-4058.

Nagele RG, D'Andrea MR, Anderson WJ, Wang HY (2002) Intracellular accumulation of $\beta$-amyloid(1-42) in neurons is facilitated by the $\alpha 7$ nicotinic acetylcholine receptor in Alzheimer's disease. Neuroscience 110:199-211.

Nogalska A, D’Agostino C, Engel WK, Klein WL, Askanas V (2010) Novel demonstration of amyloid- $\beta$ oligomers in sporadic inclusion-body myositis muscle fibers. Acta Neuropathol 120:661-666.

Perry EK, Perry RH, Smith CJ, Dick DJ, Candy JM, Edwardson JA, Fairbairn A, Blessed G (1987) Nicotinic receptor abnormalities in Alzheimer's and Parkinson's diseases. J Neurol Neurosurg Psychiatry 50:806-809.

Perry EK, Morris CM, Court JA, Cheng A, Fairbairn AF, McKeith IG, Irving D, Brown A, Perry RH (1995) Alteration in nicotine binding sites in Parkinson's disease, Lewy body dementia and Alzheimer's disease: possible index of early neuropathology. Neuroscience 64:385-395.

Quirion R, Martel JC, Robitaille Y, Etienne P, Wood P, Nair NP, Gauthier S (1986) Neurotransmitter and receptor deficits in senile dementia of the Alzheimer type. Can J Neurol Sci 13:503-510.

Rebolledo DL, Minniti AN, Grez PM, Fadic R, Kohn R, Inestrosa NC (2008) Inclusion body myositis: a view from the Caenorhabditis elegans muscle. Mol Neurobiol 38:178-198.

Richmond JE, Jorgensen EM (1999) One GABA and two acetylcholine re- ceptors function at the C. elegans neuromuscular junction. Nat Neurosci 2:791-797.

Schmidt ML, Schuck T, Sheridan S, Kung MP, Kung H, Zhuang ZP, Bergeron C, Lamarche JS, Skovronsky D, Giasson BI, Lee VM, Trojanowski JQ (2001) The fluorescent Congo red derivative, (trans, trans)-1-bromo-2,5-bis-(3-hydroxycarbonyl-4-

hydroxy)styrylbenzene (BSB), labels diverse $\beta$-pleated sheet structures in postmortem human neurodegenerative disease brains. Am J Pathol 159:937-943.

Selkoe DJ (2002) Alzheimer's disease is a synaptic failure. Science 298: $789-791$.

Selkoe DJ (2007) Developing preventive therapies for chronic diseases: lessons learned from Alzheimer's disease. Nutr Rev 65:S239-243.

Simmons SO, Fan C-Y, Yeoman K, Wakefield J, Ramabhadran R (2011) NRF2 oxidative stress induced by heavy metals is cell type dependent. Curr Chem Genomics 5:1-12.

Strausak D, Mercer JF, Dieter HH, Stremmel W, Multhaup G (2001) Copper in disorders with neurological symptoms: Alzheimer's, Menkes, and Wilson diseases. Brain Res Bull 55:175-185.

Toledo EM, Inestrosa NC (2009) Activation of Wnt signaling by lithium and rosiglitazone reduced spatial memory impairment and neurodegeneration in brains of an APPswe/PSEN1DeltaE9 mouse model of Alzheimer's disease. Mol Psychiatry 15:272-285, 228.

Touroutine D, Fox RM, Von Stetina SE, Burdina A, Miller DM 3rd, Richmond JE (2005) acr-16 encodes an essential subunit of the levamisoleresistant nicotinic receptor at the Caenorhabditis elegans neuromuscular junction. J Biol Chem 280:27013-27021.

Wang HY, Lee DH, D’Andrea MR, Peterson PA, Shank RP, Reitz AB (2000b) $\beta$-Amyloid(1-42) binds to $\alpha 7$ nicotinic acetylcholine receptor with high affinity. Implications for Alzheimer's disease pathology. J Biol Chem 275:5626-5632.

Wang HY, Lee DH, Davis CB, Shank RP (2000a) Amyloid peptide A $\beta(1-$ 42 ) binds selectively and with picomolar affinity to $\alpha 7$ nicotinic acetylcholine receptors. J Neurochem 75:1155-1161.

Wang XJ, Hayes JD, Higgins LG, Wolf CR, Dinkova-Kostova AT (2010) Activation of the NRF2 signaling pathway by copper-mediated redox cycling of para- and ortho-hydroquinones. Chem Biol 17:75-85.

Wevers A, Monteggia L, Nowacki S, Bloch W, Schutz U, Lindstrom J, Pereira EF, Eisenberg H, Giacobini E, de Vos RA, Steur EN, Maelicke A, Albuquerque EX, Schroder H (1999) Expression of nicotinic acetylcholine receptor subunits in the cerebral cortex in Alzheimer's disease: histotopographical correlation with amyloid plaques and hyperphosphorylated-tau protein. Eur J Neurosci 11:2551-2565.

Wruck CJ, Gotz ME, Herdegen T, Varoga D, Brandenburg LO, Pufe T (2008) Kavalactones protect neural cells against amyloid- $\beta$ peptide-induced neurotoxicity via extracellular signal-regulated kinase 1/2-dependent nuclear factor erythroid 2-related factor 2 activation. Mol Pharmacol 73:1785-1795.

Wu Y, Wu Z, Butko P, Christen Y, Lambert MP, Klein WL, Link CD, Luo Y (2006) Amyloid- $\beta$-induced pathological behaviors are suppressed by Ginkgo biloba extract EGb 761 and ginkgolides in transgenic Caenorhabditis elegans. J Neurosci 26:13102-13113. 